\title{
Expression of $17 \beta$-hydroxysteroid dehydrogenase types 1, 2, 3 and 4 in the human temporal lobe
}

\author{
B Stoffel-Wagner, M Watzka, S Steckelbroeck, J Schramm', \\ F Bidlingmaier and D Klingmüller
}

Department of Clinical Biochemistry, University of Bonn, 53105 Bonn, Germany

${ }^{1}$ Department of Neurosurgery, University of Bonn, 53105 Bonn, Germany

(Requests for offprints should be addressed to B Stoffel-Wagner, Institut für Klinische Biochemie, Universität Bonn, Sigmund-Freud-Str. 25, D-53105 Bonn, Germany)

\begin{abstract}
Sex steroid hormones exert important biological effects on the brain. Moreover, an extensive sex steroid metabolism occurs in the brain. In sex steroid metabolism $17 \beta$ hydroxysteroid dehydrogenases (17 $\beta$-HSDs) play essential roles in catalyzing the final steps in androgen and estrogen biosynthesis. Recently four types of human $17 \beta$-HSDs and a pseudogene of the type 1 isoform were identified. To date, $17 \beta-H S D$ has not been extensively studied in the human brain. Therefore, we investigated the mRNA expression of the four isozymes of $17 \beta-\mathrm{HSD}$ as well as the pseudogene of the type 1 isoform in the human temporal lobe to determine the predominant isoforms and, moreover, to elucidate the existence of possible sex and age differences. We studied biopsy materials from the temporal lobe of 34 women, 32 men and 10 children. Quantification of different mRNAs was achieved by competitive reverse transcription-PCR. 17 $\beta-$ HSD 1, 17 $\beta-$ HSD 3 and $17 \beta-H S D 4$ were expressed in the human temporal lobe of
\end{abstract}

children and adults, whereas 17 $\beta-$ HSD 2 and the pseudogene of $17 \beta-\mathrm{HSD} 1$ were not expressed. In adults, $17 \beta-$ HSD 3 and $17 \beta-H S D 4$ mRNA concentrations were significantly higher in the subcortical white matter $(17 \beta-$ HSD 3: $14591 \pm 3457$ arbitrary units (aU), mean \pm S.E.M.; $17 \beta-H S D$ 4: $1201 \pm 212 \mathrm{aU}$ ) than in the cortex (17 $\beta-H S D$ 3: $5428 \pm 1057 \mathrm{aU}, P<0 \cdot 0002 ; 17 \beta-H S D$ 4: $675 \pm 74 \mathrm{aU}, P<0 \cdot 004)$. 17 $\beta$-HSD 1 concentrations did not differ significantly between the white matter $(3860 \pm 1628 \mathrm{aU})$ and the cortex $(2525 \pm 398 \mathrm{aU})$ of adults. In conclusion, the present study demonstrates the expression of $17 \beta-\mathrm{HSD} 1,3$ and $4 \mathrm{mRNAs}$ in the human temporal lobe. Together with CYP19 ${ }_{\text {AROM }}$ and $5 \alpha-$ reductase, known to be expressed in the human brain, the expression of $17 \beta-\mathrm{HSD} 1,3$ and 4 mRNAs indicates the major importance of local steroid biosynthesis in the brain. Journal of Endocrinology (1999) 160, 119-126

\section{Introduction}

The brain is an important target organ of sex steroid hormones and an extensive sex steroid metabolism including aromatization and $5 \alpha$-reduction occurs in several regions of the brain (Martini \& Melcangi 1991, Lephart 1993, Naftolin 1994, Stoffel-Wagner et al. 1998a,b). Specific receptors for sex steroids have been identified in several regions of the brain, through which sex hormones could effect a genomic response (Sholl et al. 1989, Simerly et al. 1990).

In sex steroid metabolism $17 \beta$-hydroxysteroid dehydrogenases (17 $\beta$-HSDs) catalyze the final steps in androgen and estrogen biosynthesis, thus playing a crucial role in the biosynthesis and inactivation of sex steroid hormones.

Recently four types of human $17 \beta-H S D$ s were identified and their structure elucidated. Type 1 17 $\beta$-HSD, which is expressed in placenta, granulosa cells and a number of other tissues, primarily catalyzes the inter- conversion of the weak estrogen estrone (E1) and the strong estrogen estradiol (E2) with a predominance of the reductive pathway (Peltoketo et al. 1988, Luu-The et al. 1989, Dumont et al. 1992). An in-tandem pseudogene of $17 \beta-H S D 1$ has also been identified (Luu-The et al. 1990). Type $217 \beta-H S D$ is expressed in liver, placenta, endometrium and small intestine and converts E2 to E1, testosterone to androstenedione as well as the inactive progestin, $20 \alpha$-dihydroprogesterone, to the active progestin, progesterone (Wu et al. 1993). Type $317 \beta-H S D$ is an enzyme responsible for the conversion of the weak androgen androstenedione to the potent androgen testosterone, but it also catalyzes the conversion of dehydroepiandrosterone (DHEA) to androstenediol (Adiol) and E1 to E2 (Geissler et al. 1994). To date, it has been shown to be expressed only in the testes. Type $417 \beta-$ HSD is expressed in many tissues including liver, testis, ovary, prostate and heart, but not in placenta, and it preferentially inactivates E2 to E1 and also converts Adiol to DHEA (Adamski et al. 1995). 
In the 1970s the presence of $17 \beta-H S D$ activity in human fetal and adult brain (Jenkins \& Hall 1977) and rat brain (Rommerts \& van der Molen 1971, Pérez et al. 1975) had been demonstrated in a few tissue specimens, but systematic studies on $17 \beta-$ HSD activity or expression of the mRNAs of $17 \beta-H S D$ isoforms in brain tissue are lacking.

The cloning of the cDNAs of the different $17 \beta-\mathrm{HSD}$ isozymes has enabled this first investigation of the isozyme expression of $17 \beta-H S D$ s in the human brain. It was carried out on a large number of temporal lobe tissue specimens from children and adults to determine the predominant isoforms and to elucidate the existence of possible sex and age differences.

\section{Subjects and Methods}

\section{Subjects}

Biopsy materials removed at neurosurgery from 34 women (32.5 \pm 1.3 years; mean \pm s.E.M.), 32 men $(34.8 \pm 1 \cdot 6$ years) and 10 children ( 6 boys and 4 girls; $8 \pm 1 \cdot 4$ years) with temporal lobe epilepsy undergoing partial temporal lobe resection were utilized. All patients received carbamazepine (CBZ) as monotherapy or as co-medication with one additional antiepileptic drug.

\section{Tissues}

Temporal lobe biopsy materials were separated into cortex and subcortical white matter by inspection and transferred into liquid nitrogen immediately after removal and stored at $-80{ }^{\circ} \mathrm{C}$ for further use. Cortex tissue specimens were available from 19 women, 16 men and 9 children, white matter tissue specimens from 6 women, 7 men and 1 child and both cerebral cortex and white matter tissue specimens from 9 women, 9 men and 1 child.

Liver tissue $(n=3)$ was obtained from biopsies to exclude liver diseases in a transplantation program, and testis tissue $(n=4)$ from patients with prostate carcinoma undergoing orchiectomy. Adrenal tissue $(n=4)$ originated from tumoral kidneys. Placental tissue was obtained from six normal deliveries. Tissues were transferred to liquid nitrogen immediately after removal and stored at $-80{ }^{\circ} \mathrm{C}$ for further use.

The study was approved by the local ethics committee and informed consent was obtained from all tissue donors or their parents.

\section{$m R N A$ quantification}

The mRNAs of $17 \beta-H S D 1,2,3$ and 4 as well as the pseudogene of $17 \beta-$ HSD 1 were quantified with only a few modifications according to a nested competitive reverse transcription (RT)-PCR protocol previously described (Watzka et al. 1997, Waha et al. 1998).

Total RNA was extracted from 25 to $50 \mathrm{mg}$ tissue using the Trizol Reagent (Gibco-BRL, Paisley, Strathclyde, UK). Traces of DNA were removed by treatment with RNase-free DNase I (Boehringer-Mannheim, Mannheim, Germany) followed by a second RNA extraction. RNA was taken up in RNase-free water and quantified by its spectrophotometric absorption at $260 \mathrm{~nm}$.

Competitive RNA standards were prepared by twostep mutagenesis of 17 $\beta-$ HSD 3 and glyceraldehyde-3phosphate dehydrogenase (GAPDH) (Watzka et al. 1997) or single-step mutagenesis of 17 $\beta-$ HSD 1 and its pseudogene, 17 $\beta$-HSD 2 and 4 (Waha et al. 1998) resulting in the loss of 39, 23, 14, 13 and $27 \mathrm{bp}$ for 17 $\beta$-HSD 1, 2, 3, 4 and the pseudogene of $17 \beta-$ HSD 1 respectively. Successful mutagenesis was confirmed by sequencing on a semiautomated sequencer (373A, Applied Biosystems, Foster City, CA, USA). 17 $\beta$-HSD 3 and GAPDH cDNAs were cloned with the pCR-script cloning kit (Stratagene, La Jolla, CA, USA). Standard RNAs for all investigated genes were produced by in vitro transcription using an RNA in vitro transcription kit (Stratagene) with $\mathrm{T} 7$ polymerase as previously described (Watzka et al. 1997, Waha et al. 1998).

To estimate the amount of standard RNA required for quantification of individual RNA samples, three to six RNA samples of the respective tissue groups were pooled. To aliquots of these mixtures containing $250 \mathrm{ng}$ RNA each, defined amounts of standard RNAs were added. Serial dilutions ranged from $500 \mathrm{pg}$ to $5 \mathrm{ag}$ (attograms) for GAPDH and $100 \mathrm{pg}$ to $1 \mathrm{ag}$ for $17 \beta-H S D 1$ and its pseudogene, $17 \beta-$ HSD 2, 3 and 4 . Each mixture containing the respective amount of RNA standard and patient RNA was reverse transcribed followed by PCR amplification. The optimal titration point was defined as the concentration of standard RNA where PCR products yielded signals of comparable intensity for standard and native RNA (Fig. 1). A stock solution was prepared containing standard RNAs for $17 \beta-$ HSD 1 and its pseudogene, $17 \beta-H S D$ 2, 3, 4 and GAPDH at the optimal titration point. The concentration of this stock solution was selected in a way that $1 \mu \mathrm{l}$ stock was sufficient for the RT of $250 \mathrm{ng}$ total RNA. RT was performed at $42{ }^{\circ} \mathrm{C}$ for 60 min using 100 U Superscript II (Superscript preamplification System, Gibco-BRL). Resulting cDNA was diluted 20-fold with water and for GAPDH, 17ß-HSD 2, 3 and 4 PCR was performed in a final volume of $20 \mu \mathrm{l}$ containing $2 \mu \mathrm{l}$ diluted cDNA, $10 \mathrm{mM}$ Tris $-\mathrm{HCl} \mathrm{pH} 8 \cdot 3$, $40 \mathrm{mM} \mathrm{KCl}, 1.5 \mathrm{mM} \mathrm{MgCl} 2,200 \mu \mathrm{M}$ of each dNTP, $0.5 \mathrm{U}$ Taq polymerase (Boehringer-Mannheim) and 4 pmol of each primer (Table 1). Primers were obtained from Genosys, Cambridge, UK or Applied Biosystems. Primers used for GAPDH have previously been published (Watzka et al. 1997). For $17 \beta-$ HSD 1 and its pseudogene, 
Table 1 Primers used for amplification. f, forward primer; r, reverse primer; fn, nested forward primer; rn, nested reverse primer; mut, primer used for two-step mutagenesis or single-step mutagenesis; T7 f mut, primer used for single-step mutagenesis

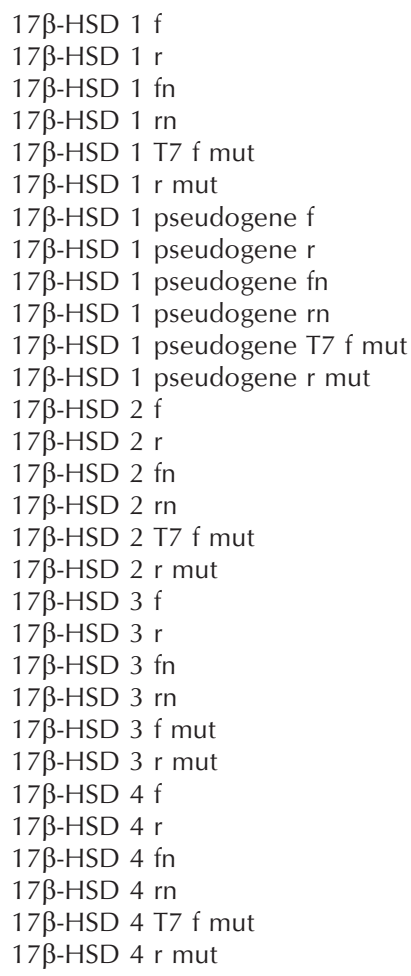

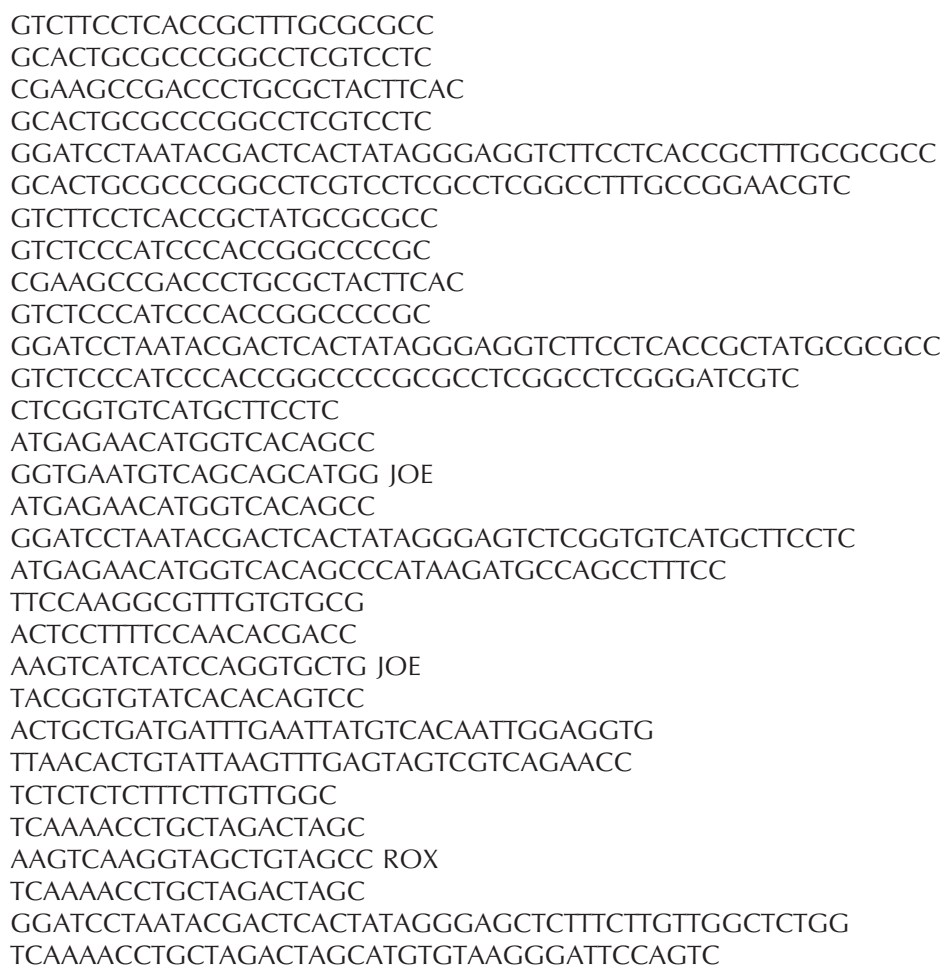

Abbreviations for fluorescent dyes: JOE, 2',7'-dimethoxy-4',5'-dichloro-6-carboxyfluorescein; ROX, 6-carboxy-X-rhodamine.

recombinant Pfu polymerase (Stratagene) instead of Taq polymerase was used. One primer of the primer pairs used for GAPDH PCR or nested PCR (17 $\beta-$ HSD 2, 3 and 4) was labeled with fluorescent dye. For $17 \beta-$ HSD 1 and its pseudogene fluorescently labeled primers did not work due to the demanding primer sequences, which could not be avoided because of the highly homologous sequences. In these cases we used unlabeled primers, agarose gel electrophoresis (4\%: agarose type I low electroendosmosis, Sigma, Deisenhofen, Germany, and NuSive agarose, FMC Bio Products, Rockland, ME, USA, 2\% each). Standard and wild type PCR products were detected with GelDoc System 1000 (BioRad, München, Germany). PCR amplification was carried out in microtiter plates in an Unoblock (Biometra, Göttingen, Germany). Initial denaturation at $94{ }^{\circ} \mathrm{C}$ for $4 \mathrm{~min}$ was followed by 32 (GAPDH) or 35 (17 $\beta-H S D ~ 2,3$ and 4) PCR cycles. Cycling conditions were $94{ }^{\circ} \mathrm{C}$ for $35 \mathrm{~s}, 55^{\circ} \mathrm{C}$ for $50 \mathrm{~s}$ and $72{ }^{\circ} \mathrm{C}$ for $90 \mathrm{~s}$. A final extension step of $5 \mathrm{~min}$ at $72^{\circ} \mathrm{C}$ was added. Nested PCR of $17 \beta-$ HSD 2,3 and 4 was performed under the same conditions. For $17 \beta-\mathrm{HSD} 1$ and its pseudogene, the initial denaturation at $95{ }^{\circ} \mathrm{C}$ for $6 \mathrm{~min}$ was followed by 35 PCR cycles. Cycling conditions were
$95{ }^{\circ} \mathrm{C}$ for $40 \mathrm{~s}, 62{ }^{\circ} \mathrm{C}$ for $45 \mathrm{~s}$ and $72{ }^{\circ} \mathrm{C}$ for $120 \mathrm{~s}$. A final extension step of $5 \mathrm{~min}$ at $72{ }^{\circ} \mathrm{C}$ was added. Nested PCR was performed under the following conditions: initial denaturation at $95^{\circ} \mathrm{C}$ for $6 \mathrm{~min}, 95^{\circ} \mathrm{C}$ for $50 \mathrm{~s}, 60^{\circ} \mathrm{C}$ for $45 \mathrm{~s}$ and $72^{\circ} \mathrm{C}$ for $80 \mathrm{~s}$ with a final extension step of $5 \mathrm{~min}$ at $72{ }^{\circ} \mathrm{C}$.

Fluorescently labeled PCR products were separated on $6 \%$ denaturing acrylamide gels $(50 \% \mathrm{w} / \mathrm{w}$ urea, 19:1 acrylamide:bisacrylamide, $1 \times \mathrm{TBE})$ and analyzed. Peak areas were calculated with the Genescan program (Applied Biosystems, Version 1.2.1). The ratio of native PCR product to standard PCR product was used for the differential determination of gene expression. Initial differences in the amounts of total RNA which were subjected to RT were corrected by calculating the ratios of native GAPDH PCR products to standard GAPDH PCR products.

\section{Statistical analysis}

Results were calculated as means \pm S.E.M. The statistical difference between groups was calculated using the 
Mann-Whitney $U$ test. $P$ values $<0.05$ were considered to reflect statistical significance.

\section{Results}

Determination of titration points for $17 \beta-H S D$ mRNAs in reference tissues and temporal lobe tissue

In order to validate our mRNA quantification protocol we determined the expression of 17 $\beta-\mathrm{HSD}$ mRNAs in placental tissue (17 $\beta-$ HSD 1 and 2$)$, testis tissue $(17 \beta$ HSD 3), liver tissue (17 $\beta$-HSD 4) and adrenal tissue (pseudogene of $17 \beta-\mathrm{HSD} 1$ ). Employment of competitive RT-PCR requires knowledge of the amount of standard RNA which yields a signal of approximately equal density when co-amplified with total RNA. The optimal titration point was $10 \mathrm{pg}$ standard RNA for 17ß-HSD 1 based on 250 ng total RNA (Fig. 1). The equivalent titration points were $1 \mathrm{pg}$ standard RNA for 17 $\beta$-HSD 2, $500 \mathrm{fg}$ standard RNA for $17 \beta-H S D 3,10 \mathrm{pg}$ for $17 \beta-H S D 4$ and $1 \mathrm{pg}$ for the pseudogene of $17 \beta-H S D$ 1. In all tissues the optimal titration point for GAPDH was $250 \mathrm{pg}$ standard RNA based on 250 ng total RNA (Fig. 1).

In the same manner the titration points of $17 \beta-H S D$ mRNAs in human temporal lobe tissue were determined. The optimal titration point was $1 \mathrm{fg}$ standard RNA for $17 \beta-H S D 1$ and $250 \mathrm{pg}$ for GAPDH based on $250 \mathrm{ng}$ total RNA, $10 \mathrm{fg}$ standard RNA for 17 $\beta-\mathrm{HSD} 3$ and $10 \mathrm{pg}$ standard RNA for $17 \beta-H S D 4$ (Fig. 1). For $17 \beta-H S D 2$ and the pseudogene of $17 \beta-H S D 1$ even an RNA standard amount of $1 \mathrm{ag}$ did not yield a detectable fluorescence signal of native RNA (Fig. 1). Conclusively, their mRNAs are not expressed in the human temporal lobe, only illegitimate transcription was detectable when the standard RNA was omitted in the RT step.

These data show that in the human temporal lobe $17 \beta$-HSD 1 mRNA concentrations were 10000 -fold lower than in the placenta, while $17 \beta-H S D 3$ mRNA concentrations were 50-fold lower than in testis tissue and $17 \beta$-HSD 4 concentrations were of the same magnitude as in liver tissue.

Expression of $17 \beta$-HSD $m$ RNAs in temporal lobe tissue from children and adults

$17 \beta$-HSD 1,3 and 4 mRNA concentrations in the cerebral cortex did not differ significantly between men and women (Table 2). 17 $\beta$-HSD 3 and 4 mRNA concentrations were significantly higher in the subcortical white matter of adults than in cortex tissue $(P<0 \cdot 0002 ; P<0 \cdot 004$; Table 2) while these differences could not be observed in $17 \beta$-HSD 1 mRNA expression. Mean 17 $\beta$-HSD 1, 3 and 4 mRNA concentrations in the cortex of children were lower than in adults, but as only a few cortex specimens from children were available a statistical analysis of the
mRNA expression in cortex tissue of adults and children was not carried out.

\section{Discussion}

Neurons and glial cells are capable of synthesizing various steroid hormones such as estrogens via CYP19 ${ }_{\text {AROM }}$ (Naftolin 1994, Stoffel-Wagner et al. 1998a) or dihydrotestosterone via $5 \alpha$-reductase (Martini \& Melcangi 1991, Stoffel-Wagner et al. 1998b). Over 20 years ago the presence of $17 \beta-H S D$ activity was demonstrated in a few human (Jenkins \& Hall 1977) and rat brain tissue specimens (Rommerts \& van der Molen 1971, Pérez et al. 1975). To date, systematic studies on $17 \beta-$ HSD activity or expression of the mRNAs of $17 \beta-H S D$ isoforms in brain tissue are lacking.

Four isozymes of $17 \beta$-HSD (type 1, 2, 3 and 4 ) and an in-tandem pseudogene of the type 1 isoform with differential tissue distribution and biochemical differences have been identified in humans (Luu-The et al. 1989, 1990, Dumont et al. 1992, Wu et al. 1993, Geissler et al. 1994, Adamski et al. 1995).

Although brain tissue homogenates are able to interconvert androstenedione to testosterone as well as E1 to E2 (Martel et al. 1992, 1994), the activity and substrate specificity of each isozyme of $17 \beta-H S D$ are greatly influenced by the in vitro conditions used for the assay, particular cofactor addition and the $\mathrm{pH}$ of the incubation. Thus, to determine which isozymes are present within a tissue, investigations on the presence of activity should be followed by an examination of mRNA for the different $17 \beta-H S D$ isozymes.

The present study is the first to determine the expression of 17ß-HSD isoforms in a large number of fresh human temporal lobe tissue specimens. The sensitive competitive RT-PCR approach used permitted us to demonstrate the expression of $17 \beta$-HSD type 1,3 and 4 in the human temporal lobe, but the pseudogene of the type 1 isoform and $17 \beta-$ HSD type 2 were not expressed.

A previous study, using Northern blot analysis (Casey et al. 1994), demonstrated that $17 \beta-\mathrm{HSD}$ type $2 \mathrm{mRNA}$ was not present in the human brain, a finding which is now confirmed by RT-PCR.

Previously, the presence of type $117 \beta-H S D$ primarily catalyzing the interconversion of E1 and E2 with a predominance of the reductive pathway was demonstrated in the rat, frog and human fetal brain using immunocytochemical techniques (Milewich et al. 1990, Pelletier et al. 1995, Mensah-Nyagan et al. 1996). We found that also in the human temporal lobe $17 \beta-H S D$ type 1 is expressed with mRNA concentrations about 10000 -fold lower than in the placenta.

Our system for quantification of $17 \beta-H S D \quad 1$ was primarily designed to distinguish between $17 \beta$-HSD 1 and its pseudogene and different splicing variants cannot 
17 BHSD 1

pseudogene

17 BHSD 2

17 ß HSD 3

17 BHSD 4

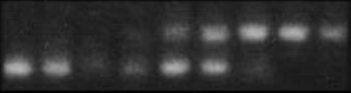

temporal lobe

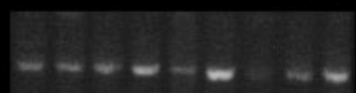

temporal lobe

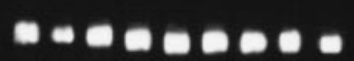

\section{temporal lobe}

๑००० -

๑ם

temporal lobe

๑๐-

•

๑๐०-

\section{placenta}

\section{placenta}

adrenal gland 
Table 2 Expression of $17 \beta$ HSD 1, $17 \beta$ HSD 3 and $17 \beta$ HSD 4 mRNAs in the human temporal lobe. Data are expressed as means \pm S.E.M. in arbitrary units

\section{$17 \beta$ HSD 1}

Tissue

Adults, cortex

Adults, swm

Children, cortex

Women, cortex

Women, swm

Men, cortex

Men, swm
$2525 \pm 398$

$(n=51)$

$3860 \pm 1628$

$(n=28)$

$1237 \pm 403$

$(n=7)$

$(n=28)$

$5933 \pm 3431$

$(n=13)$

$2739 \pm 691$

$(n=23)$

$2064 \pm 543$

$(n=15)$
$2350 \pm 459$ 17ß HSD 3

$5428 \pm 1057$

$(n=53)$

$14591 \pm 3457$ *

$(n=31)$

$3395 \pm 1506$

$(n=9)$

$7041 \pm 1909$

$(n=28)$

$11534 \pm 2459^{* * *}$

$(n=15)$

$3620 \pm 53$

$(n=25)$

$17457 \pm 6315^{* * * * *}$

$(n=16)$
$17 \beta$ HSD 4

$675 \pm 74$

$(n=53)$

$1201 \pm 212^{* *}$

$(n=31)$

$359 \pm 86$

$(n=10)$

$584 \pm 74$

$(n=28)$

$1184 \pm 204^{* * *}$

$(n=15)$

$777 \pm 133$

$(n=25)$

$1218 \pm 371^{* * * *}$

$(n=16)$

swm: subcortical white matter.

${ }^{*} P<0 \cdot 0002$, swm vs cortex tissue, ${ }^{* *} P<0 \cdot 004$, swm vs cortex tissue, ${ }^{* * *} P<0 \cdot 01$, swm vs cortex tissue,

$* * * * P<0 \cdot 05$, swm vs cortex tissue, ${ }^{* * * * *} P<0 \cdot 002$, swm vs cortex tissue.

for the runaways; regional differences within the temporal lobe itself might account for them.

$17 \beta-$ HSD type 3 concentrations were 50-fold lower in the temporal lobe than in testis tissue. To date, the presence of $17 \beta-\mathrm{HSD}$ type $3 \mathrm{mRNA}$ in brain tissue has not been reported. Since in the brain of rats and rhesus monkeys (Rommerts \& van der Molen 1971, Pérez et al. 1975, Martel et al. 1994), as well as in human temporal lobe specimens (Steckelbroeck et al. 1997), androstenedione can be converted to testosterone, these interconversions may be associated with the type 3 isoform. However, in a study using Northern blot analysis the expression of $17 \beta$-HSD 3 was not detected in the human brain, but only in the testes (Geissler et al. 1994). This discrepancy probably results from either the 50-fold lower expression of this isoform in the temporal lobe compared with testis tissue reaching the borders of sensitivity of Northern blot analysis, or from differences in the brain region under investigation. These, however, were not further identified by Geissler and his coworkers.

Type $417 \beta-H S D$ was also expressed in the human temporal lobe with mRNA concentrations of the same magnitude as in liver tissue. Northern blot analysis of $17 \beta-H S D$ type 4 in various human tissues, including brain tissue, revealed a widespread expression of the enzyme (Adamski et al. 1995). The formation of E1 from E2 has been demonstrated in various rat tissues including the brain (Martel et al. 1992). This interconversion may be associated with $17 \beta-\mathrm{HSD}$ type 4 , as $17 \beta-\mathrm{HSD}$ type 2 mRNA was not expressed in the brain.
The expression of $17 \beta-\mathrm{HSD} 1,3$ and 4 in the temporal lobe did not differ between sexes. 17 $\beta$-HSD 4 concentrations were lower in the cortex of children than in that of adults. 17 $\beta$-HSD 4 activity favors the oxidation of the most potent estrogen E2 to the weak estrogen E1 so as to inactivate estrogens. Recently, we demonstrated in the same tissue specimens that $\mathrm{CYP}_{19}{ }_{\mathrm{AROM}}$ expression is significantly lower in the cortex of children than in that of adults (Stoffel-Wagner et al. 1998a). Thus, in children local E2 formation from testosterone via CYP19 ${ }_{\mathrm{AROM}}$ might be lower than in adults and this might reduce the need for an enzyme that inactivates E2.

In the subcortical white matter of adults, $17 \beta-$ HSD 3 and 4 mRNA concentrations were significantly higher than in cortex tissue, whereas for $17 \beta-H S D 1$ mRNA expression this difference did not reach significance. Recently we demonstrated in a few human temporal lobe specimens that the conversion of androstenedione to testosterone was significantly higher in the subcortical white matter than in cortex tissue of both men and women (Steckelbroeck et al. 1997). These data support the finding of higher 17 $\beta$-HSD 3 mRNA levels in white matter than in cortex tissue. In the rat and frog brain, 17 $\beta-H S D$ 1 -immunoreactive material appeared to be present only in glial and ependymal cells (Pelletier et al. 1995, MensahNyagan et al. 1996). 17 $\beta$-HSD 3 and 4 immunoreactivity have not been studied to date. Our data confirm the predominant $17 \beta-$ HSD expression in non-neural cells and suggest that glial cells could play an important role in the biosynthesis and inactivation of sex steroid hormones. On 
the other hand, glial cells are involved in the formation of myelin, suggesting a possible correlation between sex steroids, these enzymatic activities and the formation of myelin, or with its functions.

The importance of $17 \beta$-HSDs in the maintenance of physiological levels of E2 or testosterone is supported by its ubiquitous distribution in the human (Martel et al. 1992, 1994). The expression and regulation of the counteracting enzymes CYP19 ${ }_{\text {AROM }}$ and $17 \beta-H S D 1$ on the one hand and $17 \beta-H S D 4$ on the other hand in the human temporal lobe might well determine the estrogenic microenvironment and may be important in terms of intracrine and paracrine effects in the brain. The brain might possess the ability to adjust the rate of sex steroid formation according to its individual needs.

Temporal lobe specimens used for our study were from patients who were treated with either CBZ as monotherapy or as co-medication with another antiepileptic drug. It has been reported that CBZ interacts competitively with enzymes of the cytochrome P450 superfamily such as CYP17 in testicular tissue (Kühn-Velten et al. 1990); effects on the mRNA expression of these enzymes or on the expression as well as the activity of $17 \beta-$ HSDs have not yet been reported. If there is an unknown effect of CBZ on the mRNA expression of $17 \beta-H S D$ s in the brain, it would be the same for all subjects under investigation.

In conclusion, the present study demonstrates for the first time the expression of $17 \beta$-HSD 1, 3 and 4 mRNAs in a large number of temporal lobe specimens from children and adults, but $17 \beta-\mathrm{HSD} 2$ mRNA and the pseudogene of $17 \beta-$ HSD 1 were not expressed. Together with CYP19 ${ }_{\text {AROM }}$ and $5 \alpha$-reductase, which are known to be expressed in the human brain, the expression of $17 \beta$-HSD 1,3 and 4 mRNAs indicates the major importance of local steroid biosynthesis in the brain.

\section{Acknowledgements}

This work was supported by the Deutsche Forschungsgemeinschaft by grant Kl 524/4-1. We thank Prof. M Nuri, Waldkrankenhaus Bonn, Department of Urology, for supply of testis tissue, Dr P Albers, University of Bonn, Department of Urology, for supply of adrenal tissue, Dr R K Schmutzler, University of Bonn, Department of Gynecology and Obstetrics, for supply of placental tissue, and Dr M Wolff, University of Bonn, Department of Surgery, for supply of liver tissue.

\section{References}

Adamski J, Normand T, Leenders F, Monté D, Begue A, Stéhelin D, Jungblut PW \& De Launoit Y 1995 Molecular cloning of a novel widely expressed human $80 \mathrm{kDa} 17 \beta$-hydroxysteroid dehydrogenase IV. Biochemical Journal 311 437-443.
Casey ML, MacDonald PC \& Andersson S 1994 17ß-Hydroxysteroid dehydrogenase type 2: chromosomal assignment and progestin regulation of gene expression in human endometrium. Journal of Clinical Investigation 94 2135-2141.

Dumont M, Luu-The V, De Launoit Y \& Labrie F 1992 Expression of human 17ß-hydroxysteroid dehydrogenase in mammalian cells. Journal of Steroid Biochemistry and Molecular Biology 41 605-608.

Geissler WM, Davis DL, Wu L, Bradshaw KD, Patel S, Mendonca BB, Elliston KO, Wilson JD, Russell DW \& Andersson S 1994 Male pseudohermaphroditism caused by mutations of testicular 17ß-hydroxysteroid dehydrogenase 3. Nature Genetics 7 34-39.

Jenkins JS \& Hall CJ 1977 Metabolism of $\left[{ }^{14} \mathrm{C}\right]$ testosterone by human foetal and adult brain tissue. Journal of Endocrinology 74 425-429.

Kühn-Velten WN, Herzog AG \& Müller MR 1990 Acute effects of anticonvulsant drugs on gonadotropin-stimulated and precursorsupported androgen production in the rat testis. European Journal of Pharmacology 181 151-155.

Lephart ED 1993 Brain $5 \alpha$-reductase: cellular, enzymatic, and molecular perspectives and implications for biological function. Molecular and Cellular Neurosciences 4 473-484.

Luu-The V, Labrie C, Zhao HF, Couet J, Lachance Y, Simard J, Leblanc G, Côté J, Bérubé D, Gagné R \& Labrie F 1989 Characterization of cDNAa for human estradiol $17 \beta$-dehydrogenase and assignment of the gene to chromosome 17: evidence of two mRNA species with distinct $5^{\prime}$-termini in human placenta. Molecular Endocrinology 3 1301-1309.

Luu-The V, Labrie C, Simard J, Lachance Y, Zhao H-F, Couet J, Leblanc G \& Labrie F 1990 Structure of two in tandem human $17 \beta$-hydroxysteroid dehydrogenase genes. Molecular Endocrinology 4 268-275.

Martel C, Rhéaume E, Takahashi M, Trudel C, Couet, Luu-The V, Simard J \& Labrie F 1992 Distribution of $17 \beta$-hydroxysteroid dehydrogenase gene expression and activity in rat and human tissues. Journal of Steroid Biochemistry and Molecular Biology 41 597-603.

Martel C, Melner MH, Gagné D, Simard J \& Labrie F 1994 Widespread tissue distribution of steroid sulfatase, $3 \beta$-hydroxysteroid

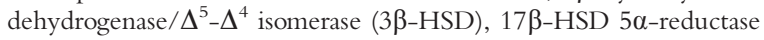
and aromatase activities in the rhesus monkey. Molecular and Cellular Endocrinology 104 103-111.

Martini L \& Melcangi RC 1991 Androgen metabolism in the brain. Journal of Steroid Biochemistry and Molecular Biology 39 819-828.

Mensah-Nyagan AM, Feuilloley M, Do-Rego JL, Marcual A, Lange C, Tonon MC, Pelletier G \& Vaudry H 1996 Localization of $17 \beta$-hydroxysteroid dehydrogenase and characterization of testosterone in the brain of the male frog. Proceedings of the National Academy of Sciences of the USA 93 1423-1428.

Milewich L, Carr BR, Frenkel RA, Marrero H, MacDonald PC \& Mason JI 1990 17ß-Hydroxysteroid oxidoreductases of human fetal and adult tissues: immunological cross-reactivity with an antihuman placental cytosolic $17 \beta$-hydroxysteroid oxidoreductase antibody. Placenta 11 95-108.

Naftolin F 1994 Brain aromatization of androgens. Journal of Reproductive Medicine 39 257-261.

Pelletier G, Luu-The V \& Labrie F 1995 Immunocytochemical localization of type I $17 \beta$-hydroxysteroid dehydrogenase in the rat brain. Brain Research 704 233-239.

Peltoketo H, Isomaa V, Möentausta O \& Vihko R 1988 Complete amino acid sequence of human placental $17 \beta$-hydroxysteroid dehydrogenase deduced from cDNA. FEBS Letters 239 73-77.

Pérez AE, Ortiz A, Cabeza M, Beyer C \& Pérez-Palacios G 1975 In vitro metabolism of ${ }^{3} \mathrm{H}$-androstenedione by the male rat pituitary, hypothalamus and hippocampus. Steroids 25 53-62.

Rommerts FFG \& van der Molen HJ 1971 Occurrence and localization of $5 \alpha$-steroid reductase, $3 \alpha$ - and $17 \beta$-hydroxysteroid dehydrogenase in hypothalamus and other brain tissues of the male rat. Biochimica et Biophysica Acta 248 489-502. 
Sholl SA, Goy RW \& Kim KL 1989 5 $\alpha$-Reductase, aromatase, and androgen receptor levels in the monkey brain during fetal development. Endocrinology 124 627-634.

Simerly RB, Chang C, Muramatsu M \& Swanson LW 1990 Distribution of androgen and estrogen receptor mRNA-containing cells in the rat brain: in situ hybridization study. Journal of Comparative Neurology 294 76-95.

Steckelbroeck S, Stoffel-Wagner B, Watzka M, Schramm J, Reichelt R, Bidlingmaier F, Schweikert HU \& Klingmüller D 1997 Quantification of $17 \beta$-hydroxysteroid dehydrogenase activity in human brain tissue. 79th Annual Meeting, The Endocrine Society, Minneapolis (USA), 11-14 June 1997, p 209 (Abstract P1-298).

Stoffel-Wagner B, Watzka M, Steckelbroeck S, Schwaab R, Schramm J, Bidlingmaier F \& Klingmüller D 1998a Expression of CYP19 (aromatase) mRNA in the human temporal lobe. Biochemical and Biophysical Research Communications 244 768-771.

Stoffel-Wagner B, Watzka M, Steckelbroeck S, Wickert L, Schramm J, Romalo G, Klingmüller D \& Schweikert HU 1998 b Expression of $5 \alpha$-reductase in the human temporal lobe of children and adults. Journal of Clinical Endocrinology and Metabolism 83 3636-3642.

Waha A, Watzka M, Koch A, Pietsch T, Przkora R, Peters N, Wiestler OD \& von Deimling A 1998 A rapid and sensitive protocol for competitive reverse transcriptase (cRT) PCR analysis of cellular genes. Brain Pathology 8 13-18.

Watzka M, Waha A, Koch A, Schmutzler RK, Bidlingmaier F, von Deimling A, Klingmüller D \& Stoffel-Wagner B 1997 An optimized protocol for mRNA quantification using nested competitive RT-PCR. Biochemical and Biophysical Research Communications 231 813-817.

Wu L, Einstein M, Geissler WM, Chan HK, Elliston KO \& Andersson S 1993 Expression cloning and characterization of human $17 \beta$-hydroxysteroid dehydrogenase type 2 , a microsomal enzyme possessing 20 $\alpha$-hydroxysteroid dehydrogenase activity. Journal of Biological Chemistry 268 12964-12969.

Received 5 May 1998

Revised manuscript received 3 September 1998

Accepted 9 September 1998 